\title{
Pengembangan Model Media Pembelajaran Audio Visual Berbasis ICT dalam Pembelajaran PJOK Pada Guru SD Negeri Se-Kecamatan Seluma
}

\author{
Development Of An Ict-Based Audio-Visual Learning Media Model In PJOK \\ For Elementary School Teachers In Seluma \\ Nurhayatun Iis Hasana $^{1}$, Tono Sugihartono ${ }^{2}$, Septian Raibowo ${ }^{3}$ \\ ${ }^{123}$ Pendidikan Jasmani, Universitas Bengkulu,Jl WR Supratman, Bengkulu, 38113, Indonesia
}

\begin{abstract}
Abstrak
Penelitian ini bertujuan untuk menghasilkan sebuah produk media pembelajaran AudioVisual berbasis ICT pada Guru PJOK SD Negeri Se-Kecamatan Seluma pada materi gerak guling ke depan. Metode penelitian yang digunakan dalam penelitain ini Research and Developement $(R \& D)$ langkah ini telah dimodifikasi sehingga langkah-langkah penggunaan metode $(R \& D)$ yang dilakukan hanya sampai langkah kelima, yaitu Revisi Desain. Penelitian ini di lakukan pada guru PJOK SD Negeri Se-Kecamatan Seluma dengan 7 Sekolah dan 7 orang guru PJOK. Teknik analisis data yang digunakan adalah pendekatan kualitatif. Media Pembelajaran Audio Visual Berbasis ICT dalam penelitian ini berupa hasil validitas produk dari ahli materi memiliki jumlah presentase $96 \%$ yang masuk dalam kategori "Sangat Layak" dan ahli media memiliki jumlah presentase 94\% yang masuk dalam kategori "Sangat Layak" sedangkan hasil validasi yang dilakukan oleh guru PJOK SD Negeri Sekecamatan Seluma, menunjukan Rata-rata presentase 96\% yang di kategorikan"Sangat Layak" Penelitian ini menghasilkan produk berupa media pembelajaran audio visual materi gerak guling ke depan yang dikemas dalam bentuk compact disk $(C D)$.
\end{abstract}

Kata kunci: Media Pembelajaran, Audiovisual, PJOK

\begin{abstract}
This study aimed to produce an ICT-based AudioVisual instructional media product for PJOK teachers at SD Negeri Sekecamatan Seluma on the material of forward rolling. The method Research and Devloment $(R \& D)$ this step has been modified so that the steps for using the method (R\&D) are carried out only up to the fifth step.This Research on PJOK teachers at SD Negeri District with 7schools and 7 PJOK teachers. The date in the form of product validity is obtained using a questionnaire and evaluation sheet made to order. The data analysis technique used is a qualitative. ICT-based audio visual learning media in this Research is the result of product validity from material is experts which has a percentage of $96 \%$ in the "Very Approriate" category and media experts have a percentage of $94 \%$ in the "Very Approriate" validation carried out by the PJOK teachers SD Negeri Seluma, showed an average percentage of $96 \%$ which was category as "Very Approriate. (CD).
\end{abstract}

Keywords: Learning Media, Audiovisual, PJOK 



\section{PENDAHULUAN}

Dalam memasuki era globalisasi sekarang ini, lembaga pendidikan mempunyai tanggung jawab mempersiapkan dan menghasilkan sumberdaya manusia yang mampu menghadapi semua tantangan perubahan yang ada di sekitarnya yang berjalan sangat cepat Untuk menghadapi era baru information and communication technology (ICT) diperlukan pendidikan yang dapat membentuk generasi kreatif, inovatif, serta kompetitif. Hal tersebut salah satunya dapat dicapai dengan cara mengoptimalisasi penggunaan teknologi sebagai alat bantu pendidikan yang diharapkan mampu menghasilkan output yang dapat mengikuti atau mengubah zaman menjadi lebih baik. Dalam menyikapi perkembangn dan kemajuan information and communication technology (ICT) tersebut, guru di tuntut untuk menguasai teknologi agar dapat mengembangkan materi-materi pembelajaran berbasis ICT dan memanfaatkan ICT sebagai media pembelajaran, tujuannya adalah untuk memberikan kemudahan dan kesempatan yang lebih luas kepada pembelajaran dalam belajar. Guru dituntut untuk menguasai teknologi agar dapat mengembangkan materi pembelajaran berbasis ICT dan menggunakan ICT sebagai media pembelajaran, dengan tujuan memberikan siswa kemudahan dalam proses dalam belajar.

Penggunaan ICT sebagai media pembelajaran dapat membantu guru dalam memberikan materi pembelajaran terkait olahraga dengan lebih mudah. Bentuk penggunaan media dalam pembelajaran olahraga dapat berupa presentasi slide, $C D$ interaktif, video tutorial, film bertema olahraga, multimedia, dan internet. Pendidikan jasmani merupakan salah satu mata ajar yang mempunyai ranah lengkap untuk mengembangkan aspek psikomotor, kognitif, dan afektif peserta didik (Nopiyanto et al, 2019).

Adapun beberapa kendala dalam menggunakan ICT sebagai media pembelajaran pendidikan jasmani, yaitu: 1) Pengendalian ada di tangan pengguna (dalam hal ini guru), oleh karena itu dalam merancang dan menggunakan ICT sebagai media pembelajaran, Guru harus desain dengan cermat agar sesuai dengan tujuan yang ingin dicapai; 2) Proses pembuatan media pembelajaran membutuhkan waktu yang lama, namun media yang dibuat dapat digunakan berkali-kali; 3) Sumber daya manusia yang terbatas, dalam hal ini guru. Beberapa guru pendidikan 
jasmani, terutama yang berada di daerah dengan kemampuan yang lebih lemah, menggunakan ICT sebagai media pembelajaran; 4) Tidak ada sentuhan manusia, ketika media digunakan untuk pembelajaran tidak akan ada interaksi sehingga hampir tidak ada faktor manusia.

Media pembelajaran olahraga mengacu pada ragam tingkah laku di sekolah, namun pada kenyataannya guru sekolah pada umumnya tidak menggunakan berbagai jenis media. Beberapa media yang paling familiar dan hampir semua sekolah menggunakan media cetak (buku) dan papan tulis. Selain itu, banyak sekolah juga menggunakan media audiovisual olahraga, seperti: film bersuara, televisi, film di televisi, dan menggunakan jenis media lain, gambar, model, dan animasi overhead dan benda nyata. Kaset audio, kaset video, VCD, slide (film bingkai foto) dan media lainnya, walaupun sebagian besar guru pendidikan jasmani sudah mengenalnya, namun masih jarang digunakan. Perlu ditekankan bahwa teknologi masih jarang digunakan, terutama bagi para guru penjas, mungkin belum memahami penggunaan teknologi, atau jumlah sarana dan prasarana yang digunakan untuk menunjang pendidikan di sekolah masih terbatas.

Video tutorial juga dapat digunakan sebagai media pembelajaran. Latihan olahraga tertentu tidak dapat dijelaskan dengan cepat karena akan segera tersedia. Kalaupun ingin menguasai aksi-aksi tersebut, siswa harus perlahan-lahan memahami berbagai tahapan atau proses, namun dalam playback audio visual guru harus mendesain sedemikian rupa: mulai dari pemilihan video, gambar, suara dan warna yang akan ditampilkan, mempersiapkan Siswa untuk LKS untuk mencapai tujuan berikut: berlatih selama proses pembelajaran, atau mempersiapkan siswa untuk mengikuti dan mendengarkan panduan pembelajaran. Hal ini dikarenakan siswa didorong untuk aktif menonton video dan mendengarkan panduan video, sehingga mendorong pembuatan konten pembelajaran di kelas menjadi lebih menarik.

Pada saat ini dunia sedang dilanda dengan adanya virus covid-19200 negara terjangkit virus ini tak terkecuali negara Indonesia. Dengan dimasa pandemi seperti ini semua beralih ke digital tidak terkecuali dengan pendidikan khususnya pendidikan indonesia. Dengan pandemi seperti ini, semua orang telah beralih ke dunia digital, termasuk pendidikan, khususnya pendidikan di Indonesia. Pemerintah 
Indonesia telah mengeluarkan kebijakan di sektor pendidikan untuk sementara waktu menghapus pembelajaran tatap muka dan mengadopsi pembelajaran online di tingkat sekolah dan universitas. Oleh karena itu, guru harus memiliki kreatifitas, inovasi dan motifasi dalam melakukan pembelajaran daring dimasa pandemi Covid-19 (Nopiyanto, 2020). Peran guru dalam menyikapi pandemi ini sangat penting untuk pemilihan media pembelajaran secara online, akan sulit bagi guru untuk memberikan materi kepada siswa secara online, terutama bagi guru penjas yang perlu memberikan materi secara rata-rata di tempat. Pada masa pandemi, guru harus berperan menunjukkan kompetensi profesional. Salah satu satu ciri guru yang profesional adalah mampu menggunakan dan memodifikasi media pembelajaran (Raibowo, Nopiyanto, \& Muna, 2020). Dalam proses pembelajaran olahraga sekolah dasar, yang dapat peneliti rujuk adalah "Pengembangan model media pembelajaran audio visual berbasis ICT dalam pembelajaran PJOK pada Guru SD NEGERI SE-KECAMATAN SELUMA". Sebagai media pembelajaran khususnya materi senam lantai, secara bertahap dapat diperluas hingga pembelajaran SD kelas 4. Media pembelajaran ini dapat membantu guru penjas dalam mengembangkan perangkat pembelajaran yang lebih sesuai di era pandemi.

\section{METODE}

Metode penelitian Research and Development (R\&D) yang digunakan dalam penelitian ini adalah metode penelitian yang digunakan untuk menghasilkan produk tertentu dan menguji keefektifan produk tersebut (Sugiyono 2010: 407). Metode R\&D adalah metode menghasilkan produk baru atau menyempurnakan produk yang sudah ada. Penelitian ini akan dilaksanakan secara tatap muka kepada guruguru PJOk SD Negeri Se-kecamatan Seluma dengan Protokol Kesehatan Covid-19 yang menuju New Normal saat ini yang sudah ditentukan.

Subjek penelitian ini adalah Guru PJOK SD Negeri Sekecamatan Seluma, yang terdiri dari 7 SD Negeri Se-Kecamatan Seluma. Sedangkan untuk objek penelitian ini adalah media pembelajaran Audio Visual yaitu materi gerak guling ke depan untuk anak Sekolah Dasar kelas IV yang di kemas dalam Compact Disk (CD).

Metode ini merupakan teknik pengumpulan data yang menjawab responden dengan memberikan rangkaian pertanyaan atau pernyataan tertulis (Sugiyono 2013: 
142). Dalam penelitian ini, metode angket digunakan untuk mengetahui kelayakan model media pembelajaran (audiovisual) berbasis ICT yang dikembangkan. Penelitian ini Gunakan skala likert dan 4 alternatif jawaban untuk menghitung skor tiap jawaban.

Tabel 1. Skoring Validasi

\begin{tabular}{cc}
\hline Kriteria & Skor \\
Sangat Baik (SB) & 4 \\
Baik (B) & 3 \\
Tidak Baik(TB) & 2 \\
Sangat Tidak Baik (STB) & 1 \\
\hline
\end{tabular}
(Sumber :Sugiyono (2016)

Rumus yang digunakan adalah

$$
\begin{array}{|l|}
P=\frac{f}{n} \times 100 \% \\
\text { Anas Sudijono, 2006:43 }
\end{array}
$$

Keterangan : $\mathrm{P}=$ presentase $\mathrm{f}=$ skor yang dipilih $\mathrm{n}=$ skor maksimal

Tabel 2. Kriteria Interprestasi Skor Uji Validitas

\begin{tabular}{lc}
\hline Persentase & Kategori \\
\hline $81 \%-100 \%$ & Sangat Layak \\
$61 \%-80 \%$ & Layak \\
$41 \%-60 \%$ & Cukup Layak \\
$21 \%-40 \%$ & Kurang Layak \\
$0 \%-20 \%$ & Sangat Kurang Layak \\
\hline
\end{tabular}

(Sumber : Arikunto, 2010)

Batas minimal dikatakan layak apabila mendapatkan persentase nilai $\geq 62 \%$ pada kategori baik.

\section{HASIL}

Produk yang dihasilkan pada penelitian ini berupa media pembelajaran Audio visual materi gerak gulimg ke depan dalam bentuk CD interaktif untuk anak SD kelas IV Rincian produk penelitian sebagai berikut : 


\section{Deskripsi Produk}

Produk yang dihasilkan dalam penelitian ini berupa buku teks teknis bergulir maju, dan dalam bentuk CD interaktif audio visual untuk siswa dalam bentuk pembelajaran (SD). Oleh karena itu, media pembelajaran audiovisual diharapkan dapat memberikan pengetahuan kepada siswa, serta dapat mempromosikan dan membantu guru PJOK dalam proses pembelajaran.

\section{Hasil Pengujian Pertama.}

Berdasarkan hasil pengumpulan data produk yang dikembangkan, berikut adalah pengenalan hasil pengujian yang dilakukan oleh peneliti. Hasil pengumpulan data meliputi data evaluasi dari ahli materi, ahli media, dan angket respon guru. Hasil evaluasi pakar digunakan sebagai dasar untuk merevisi produk yang sedang dikembangkan.

\section{Hasil Validasi Guru PJOK SD Negeri Se-Kecamatan Seluma.}

Berdasarkan hasil yang ditegaskan oleh guru, kualitas dari kedua aspek tersebut dapat dilihat yaitu tampilan materi dan program media pembelajaran berbasis ICT. Validasi guru diperlukan, karena guru akan lebih mengenal karakter siswa dan pemahaman terhadap media pembelajaran agar berjalan dengan baik.

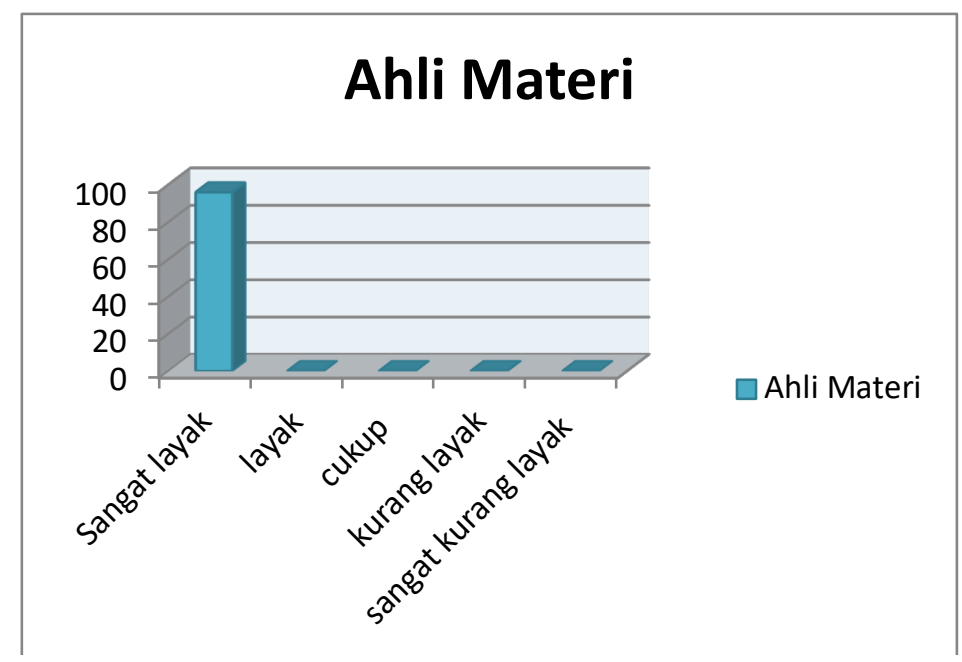

Gambar 1. Diagram Batang Hasil Validasi Tahap I Ahli Materi 
Nurhayatun lis Hasana, Tono Sugihartono, Septian Raibowo

Pengembangan Model Media Pembelajaran Audio Visual Berbasis ICT dalam Pembelajaran PJOK Pada Guru SD Se- Kecamatan Seluma

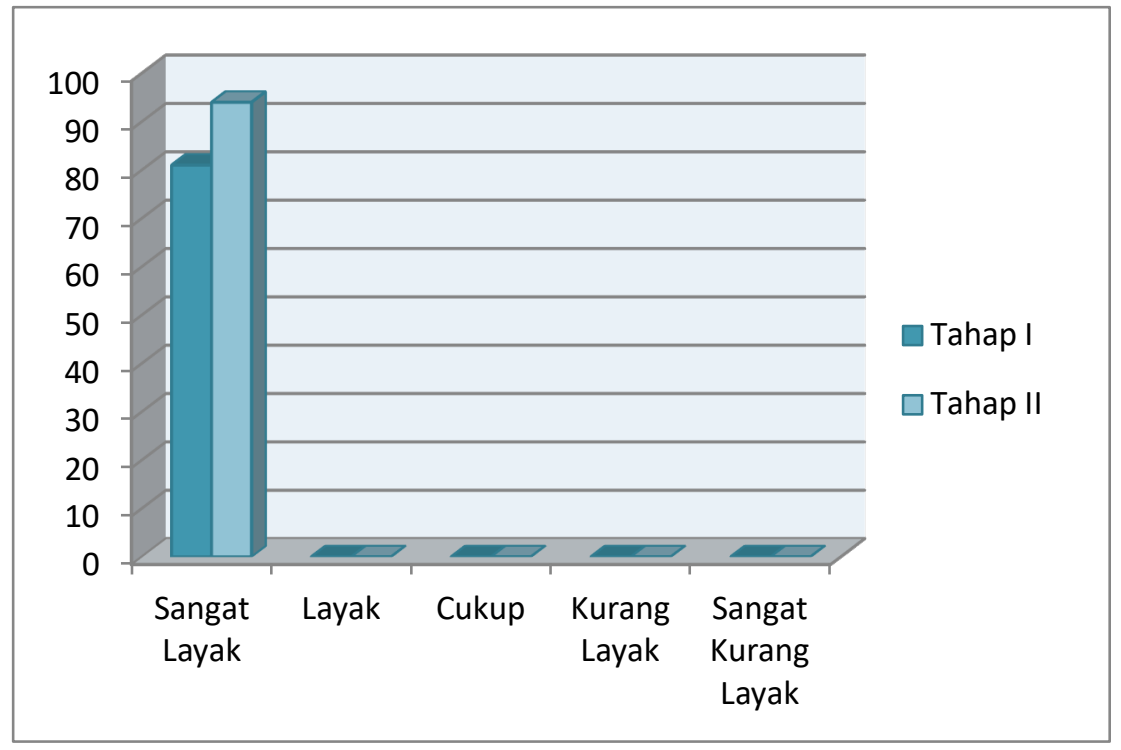

Gambar 2. Diagram Batang Hasil Validasi Tahap I dan II Ahli Media

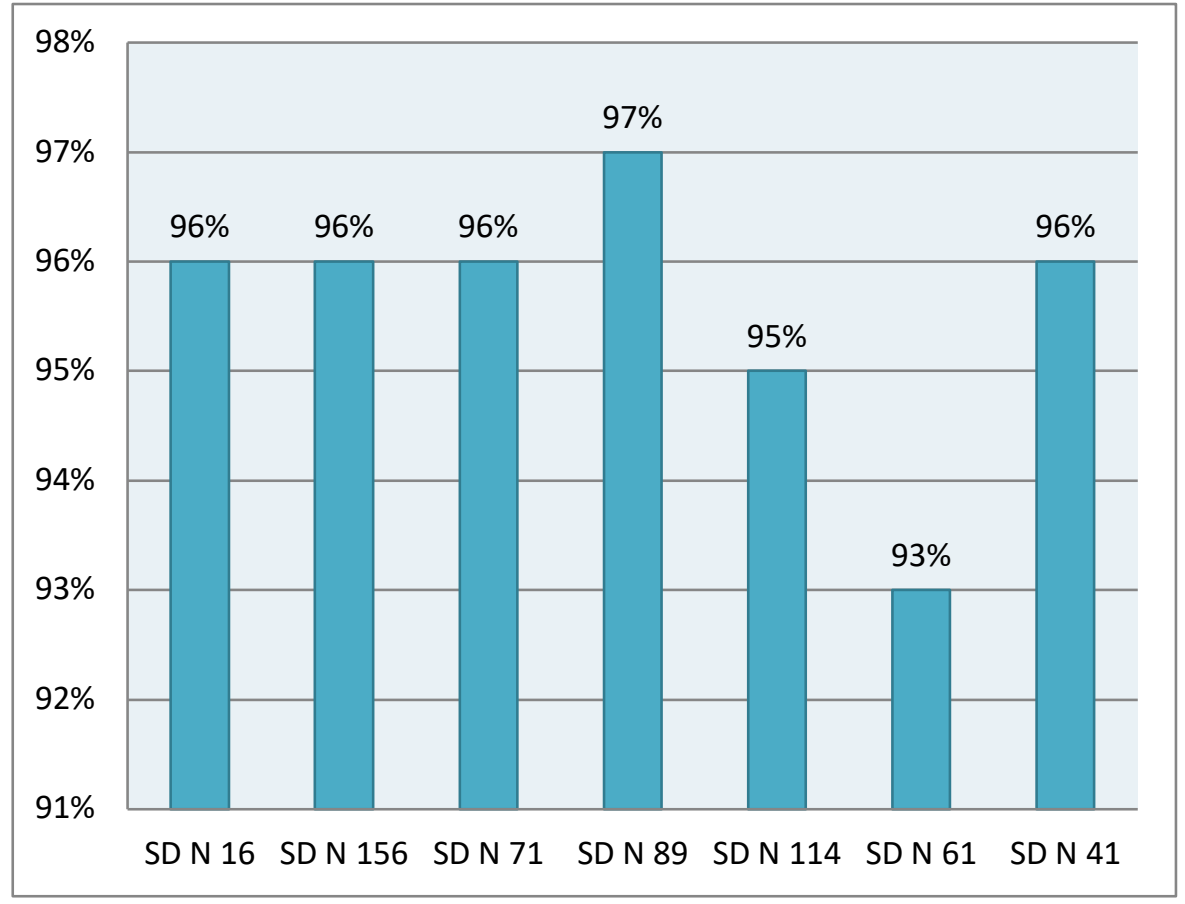

Gambar 3. Diagram Hasil Angket Tanggapan Guru PJOK SD Negeri Sekecamatan Seluma

\section{PEMBAHASAN}

Pada awal pengembangan media pembelajaran ini dirancang dan diproduksi dalam bentuk Compact Disk (CD) sebagai produk awal, digunakan untuk 
pembelajaran gerak guling ke depan dan sebagai bahan ajar bagi guru PJOK SD Negeri Sekecamat Seluma. Proses pengembangan dilakukan melalui prosedur penelitian dan pengembangan. Kemudian gunakan Microsoft Power Point untuk mengembangkan produk dan merekamnya di layar, lalu mengemasnya ke dalam compact disc (CD). Pada CD media pembelajaran terdapat video yang menjelaskan tentang tujuan, manfaat, dan video pemanasan sebelum senam, serta tutorial tentang senam gerak guling ke depan. Media pembelajaran ini untuk membantu pembelajaran pada masa pandemi seperti ini, media pembelajaran video tidak hanya cenderung pada bidang pembelajaran psikomotor, guru juga dapat menambahkan materi pada bidang kognitif, LKPD merupakan salah satu komponen yang harus dimasukkan dalam proses pembelajaran PJOK. LKPD ini bisa membantu peserta didik lebih memahami materi yang di berikan, dengan adanya penambahan LKPD guru bisa memberikan tugas tambahan dirumah kepada peserta didik guna siswa mendapatkan nilai dari pembelajaran Audio Visual yang diberikan secara daring. Sebagaimana yang diketahui bahwa pada proses pembelajaran daring harus bisa dilakukan kapanpun dan dimanapun (Raibowo \& Nopiyanto, 2020).

Setelah produk awal dihasilkan maka perlu dievaluasi kepada para ahli melalui validasi ahli, terdapat 2 ahli dalam memvalidasi produk ini yaitu validasi ahli materi dan validasi ahli media. Tahap evaluasi dilakukan pada ahli. Sedangkan tahap penelitian dilakukan dengan validasi Guru PJOK SD Negeri Sekecamatan Seluma. Proses validasi ahli dilkakukan menggunakan dua tahap. Tahap pertama masih dalam kategori layak sehingga banyak masukan dari ahli untuk perbaikan media pembelajaran. Data validasi tahap I dijadikan dasar untuk merevisi produk, setelah revisi yang pertama produk divalidasi lagi hingga siap digunakan untuk media pembelajaran. Hasil uji angket kepada ahli materi menunjukkan tingkat relevansi kedalam segala aspek dari apek kelayakan isi, kesesuaian, media yang digunakan, pengopratoran serta kejelasan masuk dalam kategori "sangat layak". Pengujian Kepada Guru PJOK SD Negeri Se-Kecamatan Seluma. Kualitas media pembelajaran dari segi aspek dikategorikan dalam kriteria "sangat layak" sebagai media pembelajaran pernyataam tersebut dibuktikan dari hasil akhir analisis penilaian dari kedua ahli, serta dalam penilaian guru SD Negeri Sekecamatan 
Seluma yang terdapat 7 Sekolah juga menghasilkan kategori "Sangat Layak" dengan presentase Rata-rata 96\% .

Setelah dilakukan uji coba produk, kelebihan dan kekurangan media pembelajaran audio visual berbasis ICT. Kelebihan Produk ini sebagai berikut, menjadi pemandu belajar siswa, Anda dapat menambah pengetahuan tentang bahan ajaran senam lantai grak guling ke depan, Membantu mempermudah pembelajaran PJOK berbasis online, membuat pembelajaran lebih kreatif dan inovatif serta membantu siswa lebih memahami materi yang dapat dilihat beberapa kali serta membantu dan meringankan guru dalam proses pembelajaran khususnya senam lantai, senam gerak guling ke depan di masa pandemi seperti ini.

Keunggulan dari bahan ajar ini adalah adanya berbagai macam jenis media seperti audio, video, animasi, dan teks. Bahan ajar dibuat bertujuan untuk memudahkan belajar secara mandiri dan bahan ajar tersebut dibentuk menjadi sekumpulan materi cetakan, audiovisual, atau yang berbasis komputer (Raibowo, 2021). Kekurangan Produk ini yaitu biaya produksi pembuatan media pembelajaran berbasis ICT relatif mahal, durasi media pembelajaran terbatas ,materi yang disajikan dalam media pembelajaran audio visual ini hanya sebatas pada senam lantai gerak guling kedepan saja dan pembuatan dan pengujian terhambat oleh adanya pandemi virus covid-19.

\section{KESIMPULAN}

Berdasarkan hasil penelitian dapat disimpulkan bahwa pengembangan model media pembelajaran audio visual berbasis ICT pada guru SD Negeri Sekecamatan Seluma dalam pembelajaran PJOK meliputi: kelayakan "96\%, untuk ahli II tahap I, kelayakan media" sangat layak "Rasio" adalah 81\%, dan hasil akhir evaluasi dilakukan oleh para ahli pada tahap kedua kelayakan media tahap kedua, rasio "sangat layak" adalah 94\%, dan kualitas keseluruhan media pembelajaran audiovisual SD Negeri Sekecamatan Seluma Jawaban guru PJOK kategori sangat layak yaitu sebesar 96\%. Implikasi penelitian Mengembangkan produk media pembelajaran audio visual berbasis ICT Ini dapat digunakan sendiri atau dalam kelompok kecil sebagai tatap muka dan penggunaan online sebagai sumber belajar bagi siswa. Media pembelajaran audiovisual berbasis teknologi informasi dan komunikasi. Hal ini dapat mempermudah dan membantu proses pembelajaran guru 
PJOK Penelitian dan pengembangan media pembelajaran Audio Visual berbasis ICT ini memiliki beberapa saran, yaitu: Materi yang dikenalkan pada media pembelajaran audio visual berbasis ICT Ini hanya sebatas pengembangan media senam gerak guling ke depan, Penelitian dan pengembangan ini baru pada tahap penentuan kelayakan media pembelajaran audio visual berbasis ICT, Media pembelajaran audio visual berbasis ICT yang dikembangkan dapat digunakan sebagai acuan untuk pengembangan media pembelajaran lainnya.

\section{REFERENSI}

Arsyad, Azhar. (2011). Media Pendidikan. Jakarta: PT Raja Grafindo Persada.

Darmawan, D. (2012). Pendidikan Teknologi Informasi dan Komunikasi. Bandung: PT Remaja Rosdakarya.

Daryanto, (2016). Media Pembelajaran. Yogyakarta:Gava Media.

Nopiyanto, Y. E. \& Raibowo, S. (2019). Filsafat pendidikan jasmani dan olahraga.

Bengkulu: Zara Abadi.

Nopiyanto, Y. E. (2020). Hambatan Guru Pendidikan Jasmani Generasi 80-an dalam Pembelajaran Daring di Tengah Pandemi Covid-19. Jurnal Sporta Saintika, 5(2), 139-148.

Raibowo, S., Adi, S., \& Hariadi, I. (2020). Efektivitas dan Uji Kelayakan Bahan Ajar Tenis Lapangan Berbasis Multimedia Interaktif. Jurnal Pendidikan: Teori, Penelitian, dan Pengembangan, 5(7), 944-952.

Raibowo, S., \& Nopiyanto,Y. E. (2020). Proses Belajar Mengajar PJOK Di Masa Pandemi Covid-19. STAND: Journal Sport Teaching and Develoment, 1(2), $112-119$

Raibowo, S., Nopiyanto, Y. E., \& Muna, M. K. (2020). Pemahaman Guru PJOK Tentang Standar Kompetensi Profesional. Journal Of Sport Education (JOPE), 2(1), 10-15.

Salameh.A, Khawaldeh.A (2014). Pengaruh Kesesuaian Tugas-Teknologi,dan Keahlian . Jakarta : Media Pusindo.

Sugiyono, (2010). Metode Penelitian Pendidikan Kuantitatif, Kualitatif dan R\&D. Bandung:Alfabeta. 